\title{
16. In kind benefits as partial payment of a living wage
}

Since in kind benefits can be an important component of remuneration, it is important to determine their monetary value. How to value in kind benefits is controversial. Workers, trade unions, and governments are concerned about potential abuse, even though they recognize that in kind benefits can be of personal value to workers. Employers think that in kind benefits should be considered as partial payment of wages as a matter of fairness - in part because in kind benefits are often an important business expense and in part because in kind benefits benefit workers.

Given the controversial backdrop and the importance of in kind benefits, an analysis of how in kind benefits are treated as partial payment of wages in national laws of 162 countries was undertaken by one of the authors (Anker and Anker, 2015). ILO Conventions and Recommendations were also reviewed. This report is, as far as we know, the most comprehensive analysis to date of in kind benefits as partial payment of wages. This chapter draws on that analysis to develop guidelines and principles on how to value in kind benefits as partial payment of a living wage that would be considered fair and reasonable by workers and employers.

Part I provides background information on what in kind benefits are, their history of abuse, and how national laws around the world and ILO Conventions and Recommendations treat in kind benefits as partial payment of wages. Part II discusses principles, approaches and recommended guidelines for valuing in kind benefits as partial payment of a living wage. This discussion draws on Part I as well as living wage studies conducted for the Global Living Wage Coalition. Part III provides examples.

\section{PART I. BACKGROUND}

\subsection{What Are In Kind Benefits?}

\subsubsection{Definition of in kind benefits}

According to the OECD glossary of statistical terms (2002): 
Payments in kind are goods and services furnished to employees free of charge or at markedly reduced cost that are clearly and primarily of benefit to the employee as consumers. They comprise food, drink, fuel and other payments in kind; and cost, other than capital cost, of workers' housing borne by employers (cost for employer owned dwellings, cost of dwellings not employer owned, other housing costs).

\subsubsection{Why in kind benefits are considered as partial payment of living wage}

In kind benefits reduce the cash wage that workers require for living expenses. When workers receive essential goods and services such as free meals, free housing, or free transport to work, their need for cash income to support a basic but decent living standard is reduced. This means that it is appropriate to include a fair and reasonable monetary value for in kind benefits when determining if an employer pays a living wage and a worker receives a living wage.

In kind benefits can be an important part of remuneration and of considerable value to workers (as well as a major expense for employers). For example, we estimated that the value of in kind benefits equaled approximately $25 \%$ of wages of newly hired workers for flower farms near Lake Naivasha, Kenya (Anker and Anker, 2014). In contrast, in kind benefits were found to be unimportant in factories in China (Wang et al., 2016) and Bangladesh (Khan et al., 2016).

\subsubsection{Wide variety of in kind benefits}

Workers receive a variety of in kind benefits around the world with the most important being food, housing, and transport. In kind benefits are especially important and prevalent in certain industries (e.g. agriculture and restaurants), occupations (e.g. domestics and servers), and countries. A list of common in kind benefits is provided in Section 16.6. See Appendix 15.1 and endnotes in Section 16.6 for an indication of some of the many types of in kind benefits mentioned by employers.

\subsection{Historical Background of Abuse by Employers in Providing and Valuing In Kind Benefits}

The history surrounding in kind benefits is associated with many examples of abuse. According to a report for the International Labor Conference (ILO, 2003, p. 52), 'Historically, the payment of wages in kind has led to abuses. The method of payment known as the "truck system", or barter, as practiced by employers who exploited the wretchedness of those workers, kept the workers in a state of dependency bordering on slavery.' 
ILO reports prepared by Committees of Experts for discussion in International Labor Conferences are strewn with examples of concern about the use of in kind benefits as partial payment of minimum wages for well over half a century. In 1951, discussions for Convention 99, Minimum wage fixing machinery (Agriculture), stated 'The Workers' group expressed its intention of establishing a provision prohibiting this [in kind] form of payment of minimum wage' (ILO, 1992, p. 126). This prohibition was not included in the Convention. In 1967, 'When this matter was discussed by the Meeting of Experts in 1967, the view was expressed that the ideal situation would be to prohibit the partial payment of minimum wages in kind' (ILO, 1992, p. 126). Discussions in 1971 prior to adoption of Convention 131, Minimum Wage Fixing, indicated that, 'Once again during the Conference this point [prohibiting in kind benefits as partial payment of minimum wages] was the subject of long discussions' (ILO, 1992, p. 126).

The question of whether to include a provision in Convention No. 131 [1971] regarding the partial payment of the minimum wage in kind was submitted to member States in the questionnaire prepared by the Office for the first Conference discussion. It emerged from the responses that the ratification of a new Convention would run into difficulties if it did not include a provision authorizing the partial payment of minimum wages in kind. However, many governments felt that this practice, while it might be necessary in certain circumstances, should be discouraged. (ILO, 2014, p. 26)

\subsubsection{Consensus of cautious acceptance of in kind benefits with caveats}

The general consensus that has emerged over the years from discussions between ILO's tripartite stakeholders is that in kind benefits are a fact of life and an accepted form of wage payment around the world. At the same time, there is a consensus that it is important to set restrictions and be cautious on how in kind benefits are treated as partial payment of minimum wages in order to reduce and hopefully avoid abuse. As a 2014 ILO Committee of Experts report strongly suggested by putting the following quote in bold:

Encourage the tripartite constituents to endeavor to limit the [in kind] items included in the minimum wage to what appears to them strictly necessary in view of the situation in the country. The Committee therefore considers that caution is required in taking into account benefits in kind. (ILO, 2014, p. 27) 


\subsection{Practices in National Laws}

\subsubsection{National laws allow in kind benefits as partial payment of wages in almost all countries}

Table 16.1 presents a summary of how in kind benefits are treated in the national laws of 162 countries (Anker and Anker, 2015). It indicates that almost all countries in the world allow in kind benefits as partial payment of wages.

\subsubsection{National laws often restrict when in kind benefits can be partial payment of wages}

We found that only around $10 \%$ of countries do not allow in kind benefits as partial payment of wages. However, most countries place restrictions on when in kind benefits can be considered as partial payment of wages. The following restrictions were found in our review of national laws (Table 16.1).

\section{- Allowed only when worker agrees}

More than $40 \%$ of countries allow wages to be reduced for in kind benefits only when workers agree to this (and usually only when workers agree in writing or in a CBA). At least $70 \%$ of European countries require agreement from workers before in kind benefits can be considered as partial payment of their wages. We also found a consensus for the federal government and all five states in the United States that we looked at - employee agreement is required before an in kind benefit can be considered as partial payment of wages. ${ }^{1}$

- Allowed only in special circumstances

At least 7\% of countries allow in kind benefits as partial payment of wages only when workers are transferred away from home or when work is in a remote area. This restriction occurs mainly in Arab States and Africa (that includes Egypt and Libya).

- Allowed only in certain occupations, industries and locations

At least $12 \%$ of countries allow in kind benefits as partial payment of wages only in occupations, industries and locations where it is customary.

- Not allowed as partial payment of minimum wage

At least $12 \%$ of countries do not allow in kind benefits to reduce cash wage received to less than minimum wage. 


\section{Table 16.1 Summary of how in kind benefits are treated as partial payment of wages, 162 countries}

\begin{tabular}{|l|c|c|c|c|c|c|}
\hline $\begin{array}{l}\text { Can in kind benefits be } \\
\text { considered as partial } \\
\text { payment of wages? }\end{array}$ & $\begin{array}{c}\text { Africa } \\
(\mathrm{N}=50)\end{array}$ & $\begin{array}{c}\text { Arab } \\
\text { States } \\
(\mathrm{N}=10)\end{array}$ & $\begin{array}{c}\text { Americas } \\
(\mathrm{N}=34)\end{array}$ & $\begin{array}{c}\text { Asia } \\
(\mathrm{N}=28)\end{array}$ & $\begin{array}{c}\text { Europe } \\
(\mathrm{N}=40)\end{array}$ & $\begin{array}{c}\text { Total } \\
(\mathrm{N}=162)\end{array}$ \\
\hline $\begin{array}{l}\text { No (no apparent } \\
\text { qualifiers) }\end{array}$ & $8 \%$ & $30 \%$ & $3 \%$ & $29 \%$ & $3 \%$ & $10 \%$ \\
\hline $\begin{array}{l}\text { Yes (but only for workers } \\
\text { in special situations such } \\
\text { as transfer of } \\
\text { workplace or work } \\
\text { in remote area) }\end{array}$ & $18 \%$ & $20 \%$ & $3 \%$ & $0 \%$ & $0 \%$ & $7 \%$ \\
\hline $\begin{array}{l}\text { Yes (but only } \\
\text { when customary } \\
\text { in an occupation } \\
\text { or industry such as } \\
\text { agriculture, domestic, } \\
\text { and restaurant) }\end{array}$ & $16 \%$ & $0 \%$ & $15 \%$ & $11 \%$ & $10 \%$ & $12 \%$ \\
\hline $\begin{array}{l}\text { Yes (only when } \\
\text { employee agrees) }\end{array}$ & $18 \%$ & $0 \%$ & $15 \%$ & $21 \%$ & $25 \%$ & $19 \%$ \\
\hline $\begin{array}{l}\text { Yes (only when written } \\
\text { agreement } \\
\text { or CBA) }\end{array}$ & $10 \%$ & $10 \%$ & $18 \%$ & $21 \%$ & $45 \%$ & $22 \%$ \\
\hline $\begin{array}{l}\text { Yes (but cannot reduce } \\
\text { cash wage to less than } \\
\text { cash minimum } \\
\text { wage) }\end{array}$ & $4 \%$ & $10 \%$ & $18 \%$ & $7 \%$ & $20 \%$ & $12 \%$ \\
\hline $\begin{array}{l}\text { Yes (no apparent } \\
\text { qualifiers) }\end{array}$ & $30 \%$ & $32 \%$ & $14 \%$ & $15 \%$ & $25 \%$ \\
\hline
\end{tabular}

Notes: Column totals can sum to more than $100 \%$ because countries can be in more than one category.

a Four countries that allow in kind benefits as partial payment of wages in government decrees or regulations were placed in this category because they were generally concerned with industries and occupations where in kind benefits are customary (Benin, Mali, Myanmar, and Netherlands).

b Four countries that allow in kind benefits as partial payment of wages in only certain occupations or industries without indicating if this is customary were included in this category (El Salvador, domestics; Honduras, rural; Nicaragua, agriculture and domestics; Serbia, domestics).

c Two countries that allowed in kind benefits as partial payment of wages but excluded a specific industry or occupation were included in this category (Morocco, agriculture; Bolivia, domestics).

d Three countries allow deductions for in kind benefits for only housing. They are included in yes (no apparent qualifiers) (Bahrein, the United Kingdom) and yes employee agreement required (Bangladesh). 
Table 16.1 (continued)

e When both agreement and written agreement/CBA are indicated for a country, this country is included in yes when the employee agrees (Djibouti, Eritrea, Ethiopia, Zambia, Romania).

Sources: Anker and Anker (2015).

\subsubsection{National laws often limit amount that can be deducted from pay for in kind benefits}

We found that at least 44 countries (at least $30 \%$ of countries) limit the amount or percentage of pay that can be deducted for in kind benefits. Limits are obviously set to avoid possible abuse and provide workers with sufficient agency over how they spend their earnings. The average (mean) maximum percentage of wages that can be paid in kind is $35.5 \%$ in these 44 countries, with a median of $30 \%$ (Table 16.2). Common percentages are $20 \%, 25 \%, 30 \%$, and $50 \%$. This percentage was lower than $20 \%$ in only two countries and higher than $50 \%$ in only two countries.

In addition, a number of other countries limit the amount of in kind benefits that can be considered as partial payment of wages in other ways. Statutes in at least 10 countries set specific values allowed for different in kind benefits. At least $12 \%$ of countries do not allow cash wage received to fall below minimum wage.

\subsubsection{National laws sometimes require in kind benefits to meet minimum standards}

Some countries require food and housing in kind benefits to meet minimum standards. Cameroon and Niger require lodging to correspond with an employee's family situation. Cameroon, Niger and Benin specify that the quality of lodging must be 'sufficient and decent' or 'adequate and decent.' Egypt specifies that food and housing be 'suitable,' and Yemen requires housing and food to be 'adequate.' Comoros requires housing to be 'hygienic.'

To be counted as partial payment of wages, in kind housing is required to meet minimum standards in South Africa, Mali and New York State. Housing in Mali must have 'durable structure; roof and exterior walls; windows for adequate ventilation and light; lit at night as customary in region; equipped kitchen; habitable condition; 14 cubic meters air space; hygienic toilet and 20 liters of water per day per person with potable drinking water'. ${ }^{2}$ Agricultural housing in South Africa must have 'durable waterproof roof; glass windows that open; electricity if available on farm; safe water; flush or pit toilet; at least 30 square meters of space' ${ }^{3}$ Lodging 
Table 16.2 Maximum percentage allowed for in kind benefits as partial payment of wage, 44 countries with an identified maximum percentage (also see notes to table for 10 additional countries that restrict amount by setting specific values for in kind benefits)

\begin{tabular}{|c|c|c|}
\hline Country & $\begin{array}{l}\text { Maximum } \\
\% \text { allowed }\end{array}$ & Notes \\
\hline \multicolumn{3}{|l|}{ Africa } \\
\hline Angola & $50 \%$ & $\begin{array}{l}\text { Cannot exceed market value. Food, } \\
\text { clothing \& accommodation mentioned. }\end{array}$ \\
\hline Botswana & $40 \%$ & \\
\hline Cape Verde & $50 \%$ & \\
\hline Chad & $\begin{array}{c}38 \% \\
\text { (see comment) }\end{array}$ & $\begin{array}{l}2 \mathrm{MW} \text { hours for daily rations \& } 1 \mathrm{MW} \\
\text { hour for meal. Implies } 3 / 8 \text { of MW } \\
\text { for one meal \& rations for } 8 \text {-hour } \\
\text { workday. }\end{array}$ \\
\hline $\begin{array}{l}\text { Equatorial } \\
\text { Guinea }\end{array}$ & $50 \%$ & \\
\hline Eritrea & $20 \%$ & \\
\hline Guinea Bissau & $50 \%$ & \\
\hline Mali & $\begin{array}{c}38 \% \\
\text { (see comment) }\end{array}$ & $\begin{array}{l}2.5 \mathrm{MW} \text { hours for food \& } 0.5 \mathrm{MW} \text { hour } \\
\text { for lodging. Implies } 3 / 8 \text { of } \mathrm{MW} \text { for } \\
\text { 8-hour workday. }\end{array}$ \\
\hline Mozambique & $25 \%$ & \\
\hline $\begin{array}{l}\text { Sao Tome and } \\
\text { Principe }\end{array}$ & $50 \%$ & \\
\hline Senegal & $\begin{array}{c}38 \% \\
\text { (see comment) }\end{array}$ & $\begin{array}{l}2 \mathrm{MW} \text { hours for daily rations \& } 1 \mathrm{MW} \\
\text { hour per meal. Implies } 3 / 8 \text { for one meal } \& \\
\text { rations for } 8 \text {-hour workday. }\end{array}$ \\
\hline South Africa & $\begin{array}{c}20 \% \\
\text { (agriculture) }\end{array}$ & $\begin{array}{l}10 \% \text { for food; } 10 \% \text { for accommodation. } \\
\text { For agricultural workers. }\end{array}$ \\
\hline Tanzania & $\begin{array}{c}68 \% \\
\text { (domestics) }\end{array}$ & For domestic workers \\
\hline Average $(N=13)$ & $\begin{array}{c}41 \% \\
(40 \% \text { median })\end{array}$ & \\
\hline \multicolumn{3}{|l|}{ Arab States } \\
\hline Bahrein & $25 \%$ & For housing. Only housing allowed. \\
\hline Average $(N=1)$ & $25 \%$ & \\
\hline
\end{tabular}


Table 16.2 (continued)

\begin{tabular}{|c|c|c|}
\hline Country & $\begin{array}{l}\text { Maximum } \\
\% \text { allowed }\end{array}$ & Notes \\
\hline \multicolumn{3}{|l|}{ Americas } \\
\hline Argentina & $20 \%$ & \\
\hline Brazil & $\begin{array}{c}70 \% \\
\text { (of MW) }\end{array}$ & $\begin{array}{l}\text { Percentage overstated for most employees } \\
\text { since based on minimum wage }\end{array}$ \\
\hline $\begin{array}{l}\text { Canada } \\
\text { (Manitoba) }\end{array}$ & $\begin{array}{c}20 \% \\
\text { (see comment) }\end{array}$ & $\begin{array}{l}\text { Meal valued at } \$ 1 \text {; lodging valued at } \\
\$ 7 \text { per week. } 20 \% \text { assumes lodging \& } \\
1 \text { meal per day. MW was C } \$ 10 \text { then. }\end{array}$ \\
\hline Chile & $50 \%$ & \\
\hline Colombia & $\begin{array}{c}30 \% \\
\text { (of } \mathrm{MW} \text { ) }\end{array}$ & $\begin{array}{l}\text { Food, clothing and lodging mentioned } \\
\text { for all workers. Fuel, crops also } \\
\text { mentioned for agricultural } \\
\text { workers. }\end{array}$ \\
\hline Costa Rica & $33 \%$ & Food, clothing and housing mentioned \\
\hline $\begin{array}{r}\text { Dominican } \\
\text { Republic }\end{array}$ & $50 \%$ & \\
\hline Ecuador & $25 \%$ & \\
\hline Guatemala & $30 \%$ & $\begin{array}{l}\text { Not more than cost to employer. } \\
\text { Food mentioned. }\end{array}$ \\
\hline Honduras & $30 \%$ & $\begin{array}{l}\text { Not more than cost to employer. } \\
\text { Food \& housing mentioned. }\end{array}$ \\
\hline Mexico & $\begin{array}{c}50 \% \\
\text { (domestics) }\end{array}$ & \\
\hline Nicaragua & $50 \%$ & \\
\hline Panama & $20 \%$ & \\
\hline Paraguay & $30 \%$ & Also $60 \%$ for domestics \\
\hline Average $(N=14)$ & $\begin{array}{c}36 \% \\
(30 \% \text { median }) \\
\end{array}$ & \\
\hline \multicolumn{3}{|l|}{ Asia } \\
\hline Cambodia & $\begin{array}{l}20 \% \\
\text { (see comment) }\end{array}$ & $\begin{array}{l}\text { Varies with distance from MW: } 0 \% \text { if } \\
\text { MW or less; } 20 \% \text { for } 1-3 \mathrm{MW} ; 30 \% \text { for } \\
\text { 3-10 MW; } 50 \% \text { for }>10 \mathrm{MW} \text {. Health } \\
\text { care not allowed. }\end{array}$ \\
\hline Fiji & $15 \%$ & $\begin{array}{l}5 \% \text { for housing; } 5 \% \text { for food; } 15 \% \text { for } \\
\text { board, fuel, light and accommodation. }\end{array}$ \\
\hline Indonesia & $25 \%$ & \\
\hline
\end{tabular}




\section{Table 16.2 (continued)}

\begin{tabular}{|c|c|c|}
\hline Country & $\begin{array}{l}\text { Maximum } \\
\% \text { allowed }\end{array}$ & Notes \\
\hline New Zealand & $20 \%$ & $\begin{array}{l}15 \% \text { board; } 5 \% \text { lodging. Not } \\
\text { more than cost to employer. }\end{array}$ \\
\hline $\begin{array}{l}\text { Papua New } \\
\text { Guinea }\end{array}$ & $50 \%$ & \\
\hline Average $(N=5)$ & $\begin{array}{c}26 \% \\
(20 \% \text { median })\end{array}$ & \\
\hline \multicolumn{3}{|l|}{ Europe } \\
\hline Azerbaijan & $50 \%$ & \\
\hline Belgium & $40 \%$ & \\
\hline Greece & $10-15 \%$ & \\
\hline Hungary & $20 \%$ & \\
\hline Netherlands & $\begin{array}{c}30 \% \\
\text { (domestics) }\end{array}$ & \\
\hline Portugal & $50 \%$ & Not more than market value \\
\hline Romania & $30 \%$ & \\
\hline Serbia & $\begin{array}{c}50 \% \\
\text { (domestics) }\end{array}$ & \\
\hline Spain & $30 \%$ & \\
\hline $\begin{array}{l}\text { Russian } \\
\text { Federation }\end{array}$ & $20 \%$ & \\
\hline Ukraine & $30 \%$ & \\
\hline Average $(N=11)$ & $\begin{array}{c}33 \% \\
(30 \% \text { median }) \\
\end{array}$ & \\
\hline World $(N=44)$ & $\begin{array}{l}35.5 \% \text { mean } \\
30.0 \% \text { median }\end{array}$ & $\begin{array}{l}\text { Only } 2 \text { countries }<20 \% \\
\text { Only } 2 \text { countries }>50 \% \text { (and were for } \\
\text { domestics; or relative to minimum wage) }\end{array}$ \\
\hline
\end{tabular}

Notes: $\quad$ MW indicates minimum wage.

In addition, 16 countries (approximately $10 \%$ of countries for which we had information) do not allow in kind benefits to reduce wage received in cash to below MW. This has the effect of limiting the amount wages paid in in kind benefits for many workers.

In addition, specific monetary values for in kind benefits were indicated in statutes in some countries (e.g. Burkina Faso, Comoros, Mali, Cameroon, Canada (Manitoba), United States (California, Connecticut, New York), Pakistan, Seychelles, Netherlands, United Kingdom). Setting specific amounts for different in kind benefits limits the total value of in kind benefits. For example, in Connecticut, full meals were valued at $\$ 0.85$ and light meals are valued at $\$ 0.55$; in California, breakfast was valued at $\$ 3.26$, lunch at $\$ 4.47$, and dinner at $\$ 6.01$.

Source: Anker and Anker (2015). 
in New York 'must meet generally accepted standards for protection against fire, and all structural, sanitation and similar standards in State or local laws, codes, regulations and ordinances'. ${ }^{4}$

For meals/food provided as an in kind benefit, Comoros sets types and amounts of food required. Libya requires that food consist of three meals a day in order to qualify for in kind benefit status. Mali and some states in the United States (e.g. Connecticut and New York) require that meals include a food item from three or four different food groups.

\subsubsection{National laws use a variety of methods to determine monetary value of in kind benefits as partial payment of wages}

There is no consensus on the appropriate method to use to value in kind benefits as partial payment of wages. Countries use a variety of methods and approaches. Table 16.3 indicates different methods we identified in national laws and regulations in our global review of national laws.

The most common approach relies on the general principle of 'fair and reasonable value' or similar words - which is the terminology in ILO wages conventions. This approach is used in at least Botswana, Gambia, Guinea, Swaziland, Tanzania, Uganda, Zimbabwe, Belize, Granada, the United States (federal law), Iran, Japan, Philippines, Vanuatu, and Cyprus. While 'fair and reasonable' is an excellent guiding principle, it is too vague on its own to be used in practice to determine monetary values for in kind benefits.

We found three valuation methods in national laws and codes that embody the principle of fair and reasonable.

\section{- Monetary amounts specified}

At least 10 countries indicate specific monetary amounts allowed in their labor laws - Burkina Faso, Comoros, Mali, Cameroon, Canada (Manitoba), the United States (California, Connecticut, and New York), Pakistan, Seychelles, Netherlands, and the United Kingdom. In addition, three African countries express monetary amounts for meals, food rations, and lodging in terms of the hourly minimum wage rate (Chad, Mali, and Senegal). ${ }^{5}$ Cambodia allows the percentage limit for in kind benefits to increase along with a worker's wage. It is $0 \%$ at or below the minimum wage, $20 \%$ for $1-3$ times minimum wage, $30 \%$ for $3-10$ times minimum wage, and $50 \%$ for more than 10 times minimum wage. ILO Convention 189 (ILO, 2011) mentions the possibility of valuing in kind benefits at 'prices fixed by public authorities'.

\section{- Market rates}

At least 10 countries use market rates to value in kind benefits in their laws. This includes Angola, Mozambique, Afghanistan, Fiji, 
Table 16.3 Valuation methods used in national laws and regulations to determine monetary value of in kind benefits

\begin{tabular}{|c|c|c|}
\hline Valuation method & $\begin{array}{l}\text { Number of } \\
\text { countries } \\
\text { identified }\end{array}$ & Countries \\
\hline Amount set in law & 10 & $\begin{array}{l}\text { Burkina Faso, Comoros, Mali, } \\
\text { Cameroon, Canada (Manitoba), United } \\
\text { States (California, Connecticut, New } \\
\text { York), Pakistan, Seychelles, Netherlands, } \\
\text { United Kingdom }\end{array}$ \\
\hline $\begin{array}{l}\text { At or below } \\
\text { market rate }\end{array}$ & 10 & $\begin{array}{l}\text { Angola, Mozambique, Afghanistan, } \\
\text { Fiji, India, Czech Republic, Portugal, } \\
\text { Israel, Slovakia, United States } \\
\text { (Maryland) }\end{array}$ \\
\hline $\begin{array}{l}\text { At or below cost to } \\
\text { employer }\end{array}$ & 5 & $\begin{array}{l}\text { Seychelles, Guatemala, Honduras, } \\
\text { New Zealand, Ukraine }\end{array}$ \\
\hline $\begin{array}{l}\text { Amount equal to } \mathrm{x} \\
\text { hours at minimum } \\
\text { wage rate }\end{array}$ & 3 & Chad, Mali, Senegal \\
\hline $\begin{array}{l}\text { Amount increases with } \\
\text { wage }\end{array}$ & 1 & Cambodia \\
\hline $\begin{array}{l}\text { As indicated by } \\
\text { employer }\end{array}$ & 1 & Luxembourg \\
\hline $\begin{array}{l}\text { Set by judge when } \\
\text { parties do not agree }\end{array}$ & 1 & Ecuador \\
\hline Set by experts & 1 & Colombia \\
\hline $\begin{array}{l}\text { Fair and reasonable } \\
\text { value }\end{array}$ & 15 & $\begin{array}{l}\text { Botswana, Gambia, Guinea, Swaziland, } \\
\text { Tanzania, Uganda, Zimbabwe, Belize, } \\
\text { Granada, United States, Iran, Japan, } \\
\text { Philippines, Vanuatu, Cyprus }\end{array}$ \\
\hline \multicolumn{3}{|l|}{ ILO Conventions } \\
\hline 'Fair and reasonable' & & $\begin{array}{l}\text { ILO Convention } 95 \text { (Protection of } \\
\text { Wages, 1957) and several other ILO } \\
\text { Conventions }\end{array}$ \\
\hline $\begin{array}{l}\text { 'Objective criteria such } \\
\text { as market value, cost } \\
\text { price, or prices fixed } \\
\text { by public authorities, } \\
\text { as appropriate' }\end{array}$ & & $\begin{array}{l}\text { ILO Convention } 189 \text { (Domestic } \\
\quad \text { Workers, 2011) Article } 12 \text { (2) (b) }\end{array}$ \\
\hline
\end{tabular}

Sources: Anker and Anker (2015) and ILO Conventions 95 and 189. 
India, Czech Republic, Israel, Portugal, Slovakia, and United States (Maryland). ILO Convention 189 (ILO, 2011) mentions the possibility of valuing in kind benefits at 'market value'.

\section{- Value of in kind benefits cannot exceed cost to employer}

This is used in at least five countries to prevent employers from profiting when providing in kind benefits. This includes Seychelles, Guatemala, Honduras, New Zealand, and Ukraine. ILO Convention 189 (ILO, 2011) mentions the possibility of valuing in kind benefits at 'cost price'.

\section{- Other methods}

Colombia requires unspecified experts to value in kind benefits. Luxembourg uses values indicated by the employer. Ecuador uses values set by a judge when parties do not agree.

\subsubsection{Employers in United States required to keep records and inform workers on how much is deducted from pay for in kind benefits}

Although we did not investigate this issue in our global legal review of national labor laws from 162 countries, we did look at this for five states and the Federal Government of the United States. We found that employers in all five states (New York, Texas, California, Connecticut and Maryland) are required to keep records of their costs for in kind benefits and provide workers with statements of how much they deducted from their pay for in kind benefits. This transparency provides workers with an opportunity to understand and challenge deductions that they feel are unfair.

\subsection{ILO Conventions and Recommendations and In Kind Benefits}

A number of ILO Conventions and Recommendations address issues related to in kind payment of wages. ${ }^{6}$ Their main features are described below.

\subsubsection{Three main conditions for authorizing in kind benefits as partial payment of wages}

Three main conditions are mentioned for authorizing in kind benefits as partial payment of wages in ILO Conventions and Recommendations. These are included in the ILO Protection of Wages Convention 95 (1949) Article $4(1)^{7}$ and repeated in other ILO Conventions and Recommendations. In kind benefits need to be: 
- Customary or desirable for industry or occupation.

- Appropriate for personal use and benefit of workers.

- Monetary value attributed is fair and reasonable.

\subsubsection{Monetary value of in kind benefits should be limited (one ILO Convention and one ILO Recommendation)}

ILO Convention 189 (Domestic Workers) Article 12(2) states that the monetary value of in kind benefits should be limited: 'May provide for the payment of a limited proportion of the remuneration of domestic workers in the form of payments in kind.' ILO Recommendation 201 (Domestic Workers) Article 14 elaborates further:

When provision is made for the payment in kind of a limited proportion of remuneration, Members should consider: (a) establishing an overall limit on the proportion of the remuneration that may be paid in kind so as not to diminish unduly the remuneration necessary for the maintenance of domestic workers and their families.

\subsubsection{Minimum standards for in kind benefits required (one ILO Convention and one ILO Recommendation)}

According to Plantations Convention 110 (ILO, 1958) Article 27(3) and Social Policy (Basic Aims and Standards) Convention 117 (ILO, 1962): 'Where food, housing, clothing and other essential supplies and services form part of remuneration, all practicable steps should be taken to ensure that they are adequate and their cash value properly assessed.' Article 86(2) provides detailed specifications for adequate housing: 'Minimum standards shall include specifications concerning - (a) the construction materials to be used; (b) the minimum size of accommodation, its layout, ventilation, and floor and air space; (c) verandah space, cooking, washing, storage, water supply and sanitary facilities.' Workers Housing Recommendation 115 (ILO, 1961) Articles 7 and 8 provide detailed specifications for housing standards. The Tripartite Declaration of Principles Concerning Multinational Enterprises and Social Policy (ILO, 2006) Article 34 states that 'Where they [multinational enterprises] provided workers with basic amenities such as housing, medical care or food, these amenities should be of a good standard.'

\subsubsection{Employers should be required to inform workers when in kind benefits are deducted from pay (several ILO Conventions)}

Several ILO Conventions indicate that workers should be informed of all deductions from pay including for in kind benefits. For example, ILO Convention 95 (Protection of Wages, ILO, 1949) Article 8(2) indicates that 'Workers shall be informed, in the manner deemed most appropriate by 
the competent authority, of the conditions under which and the extent to which such deductions may be made.'

\subsubsection{Worker agreement required (one ILO Convention)}

Domestics Workers Convention 189 (ILO, 2011) Article 12(2) states that measures should be 'taken to ensure such payments in kind are agreed to by workers'.

\section{PART II. PRINCIPLES AND APPROACH USED FOR VALUING IN KIND BENEFITS AS PARTIAL PAYMENT OF A LIVING WAGE}

In this section, the general approach and principles to be used for valuing in kind benefits as partial payment of living wage are discussed and guidelines are provided. These principles and guidelines are based in large part on our review of labor laws in 162 countries and ILO Conventions and Recommendations (see above and Anker and Anker, 2015). They are also based on general principles of a living wage.

\subsection{General Approach and Principles}

The approach we use to estimate the value of in kind benefits as partial payment of living wage has three steps.

- STEP 1: Decide whether an in kind benefit should be considered as partial payment of a living wage.

- STEP 2: Estimate monetary value for each acceptable in kind benefit.

- STEP 3: Ensure that the total estimated monetary value for all in kind benefits is less than maximum percentage(s) limit(s) allowed for in kind benefits.

\subsection{STEP 1: Guidelines for Determining which In Kind Benefits to Consider as Partial Payment of a Living Wage}

To be considered as partial payment of a living wage, in kind benefits need to meet the following criteria.

- Considered of benefit and value to workers or their families and for personal use

This requirement is included in national laws in many countries as well as in ILO Conventions and Recommendations. In kind benefits 
that meet this criterion reduce the cash income workers require to afford a decent standard of living. This excludes clothing and equipment for work and other in kind benefits that are not for personal use.

\section{- Meets minimum standard}

This requirement is included to ensure that provision of in kind benefits is consistent with the decency concept of a living wage. This criterion is included in laws in a number of countries as well as in the ILO Plantations Convention. This implies, for example, that housing would need to meet a minimum healthy housing standard (see chapters on housing) and that transportation would need to be safe. This could also imply that meals should be reasonably nutritious and so generally include at least three food groups: (1) food high in carbohydrates such as rice, wheat, maize, potato, cassava, or plantains; (2) protein-rich food such as beans, pulses, meats, fish, or dairy; and (3) fruits or vegetables. Despite this, we feel that researchers need to be flexible with regard to meals and housing as even poorly balanced meals, or housing that is not quite up to the local healthy housing standard can be valuable to workers. ${ }^{8}$

- Customary for an industry when estimating typical prevailing wages in an industry

This requirement is included in national laws in many countries as well as in ILO Conventions. It limits the types of in kind benefits that can be considered as partial payment of wages for an industry. This is important protection for workers.

- Received within one year

In kind benefits should be received within a year so as to be available for ongoing living expenses.

\section{- Guaranteed - not at discretion of employer}

In kind benefits should not be at the discretion or whim of the employer. Otherwise, workers would not be able to count on receiving the benefit.

- Included on following allowed list of common and desirable in kind benefits

A restricted list of common in kind benefits for the personal use of workers and their families is used in our methodology. Using this restricted list is practical, since it simplifies the work of researchers 
and auditors by not requiring them to look at all in kind benefits claimed by employers and so possibly spend considerable time valuing dubious and/or relatively inconsequential in kind benefits in terms of monetary value. This approach also helps to ensure that valuing in kind benefits as partial payment of living wage is not abused by employers who might inappropriately claim various in kind benefits. ${ }^{9}$ At the same time, the list of allowed in kind benefits includes the most important in kind benefits found around the world and the vast majority of the value of in kind benefits. This means that researchers and auditors would only need to value in kind benefits as partial payment of wages that are on the allowed list unless a very good case can be made for including other in kind benefits as partial payment of living wage.

\subsubsection{List of acceptable in kind benefits as partial payment of living wage}

a. Meals at work

b. Food rations or food commodities given for free or sold at concession rates

c. Housing (including electricity, water, and fuel)

d. Transport to and from work (and to town on weekends from agricultural estates)

e. Child care

f. School for children of workers

g. Medical clinic and medical care not required by law and not for workrelated matters

h. Medical insurance not required by law

\subsubsection{List of common in kind benefits that should not be considered as partial payment of a living wage (see Appendix 15.1 and endnotes for other in kind benefits sometimes claimed by employers)}

a. Visas or work permits for migrant workers

b. Clothing, equipment, and supplies for work

c. Dormitories or shared housing for seasonal workers ${ }^{10}$

d. Drinking water provided to workers at work

e. Land for kitchen garden

f. Charitable contributions to the community that do not go exclusively to workers

g. Employers' contributions to Social Security or National Health Service required by law 
h. Time off work for vacation, sick leave, maternity leave, or public holiday

\subsection{STEP 2: Guidelines for Determining Fair and Reasonable Value for In Kind Benefits}

The following guidelines are used to estimate the value of acceptable in kind benefits as partial payment of a living wage. They are intended to be fair and reasonable to both workers and employers. They are also intended to be cautious in how in kind benefits are valued - in keeping with the views and experiences worldwide of workers, employers and governments.

- Value of an in kind benefit should not exceed its cost to employer. This criterion prevents employers from 'profiting' on providing in kind benefits. This criterion - which is included in a number of national laws (see Table 16.3) - would be considered fair and reasonable by workers and is especially important in situations where workers have not agreed in writing or CBA to any particular valuation. Most employers would also consider this criterion fair and reasonable. After all, employers are in the business of producing shirts or bananas or whatever, and not in the business of providing lunches, transport, etc. to workers. Therefore, they would not expect to profit from the provision of in kind benefits. It also should not be forgotten that most in kind benefits help employers to run their businesses better. For example, providing a nutritious free lunch ensures that workers have sufficient nutrition to perform their work at a high level and do not faint on the job; it ensures that workers are on time for work in the afternoon; and it reduces security risks by reducing the number of times workers enter and exit the workplace. Providing free transport to a worker may be the only way to ensure a sufficient supply of workers when establishments are located in industrial zones on the outskirts of a city. Free transport to work ensures that workers are on time to work, which is especially important in locations where public transport is unreliable. In kind benefits are therefore often very advantageous to employers. As they help employers to run their business better, most employers would be unwilling to offer their workers the option of the equivalent amount in cash in place of the in kind benefits they provide. When employers are asked to indicate how much various in kind benefits cost them, they should also indicate how they estimated their costs to make sure that their values reasonably reflect their cost to employers. For example, the cost of a lunch to an employer might be the sum of the amounts 
they pay for food, kitchen staff and cooking fuel. Or, the cost of a lunch to the employer might be the amount they pay a contractor to provide lunch. Cost of transport for a worker might be the sum of the costs for petrol, driver, and depreciation, maintenance and repair of vehicle (provided that vehicle and driver are used exclusively for transport of workers to and from work; if not, a reasonable proportion of these costs should be used). Or, cost used for transport might be the cost of an outside transit company used by the establishment. Cost of housing might consist of costs for repairs and maintenance, plus depreciation and utilities. The total cost to the employer of in kind benefits should be divided by the number of employees to get the cost per employee. The reason why it is important to ask employers to indicate how they estimated their costs is to enable researchers to evaluate how realistic these estimated costs are, since in our experience many employers do not have a good idea of their costs and some exaggerate costs. Depending on responses from employers, researchers may need to make their own estimate of the cost of in kind benefits to employers, especially for important in kind benefits such as meals, housing, and transport.

- Value of an in kind benefit should not exceed its replacement cost to workers if they purchased it on the market. This criterion is included in a number of national laws (see Table 16.3), although different words are used to express this such as: 'market price', 'market value', 'market rate', 'fair market price', 'ordinary market value', 'fair price offered for sale', 'prevailing market rate', 'lowest price at which employer would sell items or provisions at retail to the public', and 'regional prices'. All of these phrases refer to what in kind benefits cost in the market place with an emphasis on this being 'fair', or 'ordinary.' This criterion would be considered fair and reasonable by workers and employers.

- Value of free meal should not exceed cost of replacing equivalent meal prepared at home. This is a criterion specific to the valuation of free meals. The reason for including this criterion is that the most relevant replacement cost of free meals to most workers is the cost of meals prepared at home that would be brought to work and not the cost of meals sold in the market. ${ }^{11}$ Note that the cost of a meal prepared at home will almost always be lower than the market price and employer cost, because meals prepared at home do not include labor costs or various overhead costs. In addition, employers sometimes provide meals that are more expensive (even at market price or at cost) than workers can afford or would choose on a daily basis. An Ethiopian farm, for example, indicated to Ergon (2012) that the free 
lunch they provide on workdays was worth around $20 \%$ of a typical wage. If the value of such meals were considered as partial payment of wages, the cash wage received by workers would not even be enough to buy sufficient nutritious food for a worker's family.

- Value of in kind benefit cannot be lower than an alternative cash allowance option offered to workers when such an option is available. Some CBAs and companies offer workers a choice between a cash allowance and a free good or service. For example, workers in the latest Kenya flower farm CBA are given a cash housing allowance when they do not have free on-farm housing. In such a situation, it is fair to consider the value of free housing to be worth at a minimum the value of the housing cash allowance option.

- When an in kind benefit is not free, such as a subsidized lunch or medical care or housing cost, for which workers have a co-pay, the cost to workers needs to be subtracted, thereby reducing the value of the in kind benefit to workers.

In summary, in our methodology, the value of acceptable in kind benefits should be estimated in several different ways. The researcher would then need to choose one of these values taking into consideration the various guidelines and points indicated above. Value used should usually be the lowest of the valuations (cost to employer, market replacement value), and subject to consideration of any co-payment by workers and maximum limit restriction (see Section 16.8).

\subsection{STEP 3: Rules for Maximum Limit(s) for Value of In Kind Benefits}

It is important from the point of view of human rights, that workers have self-determination in how to use their earnings. Also, many national laws place a maximum limit on the value of in kind benefits (see discussion on this in Part I). With this as background, the following maximum limits are used for in kind benefits as partial payment of living wage.

- Maximum value of $30 \%$ of wage for all acceptable in kind benefits allowed. $30 \%$ is the median limit for all in kind benefits as partial payment of wages found for 44 countries from around the world in our global legal review (Table 16.2). Thirty percent is high enough to amply 'reward' employers who provide decent quality in kind benefits while allowing workers agency and self-determination over how they spend most of their earnings.

- Maximum limit of $15 \%$ of wage allowed for housing and $10 \%$ for any other in kind benefits such as food or transport. Setting maximum 
allowed percentages for individual in kind benefits is common in national law to help prevent possible abuse.

- Exception of 50\% limit allowed in special situations. We feel that it is appropriate to include the possibility of a $50 \%$ maximum limit in situations where employers are obliged to provide workers and their families with all or almost all basic needs by law or by circumstances (e.g. remote location). Laws in a number of countries use a 50\% maximum limit for in kind benefits (see Table 16.2).

- Maximum value for all in kind benefits as partial payment of wage should not bring cash wage below minimum wage when this restriction is stipulated in law. In locations where laws do not allow in kind benefits to reduce cash wage below minimum wage, this restriction should be honored. These countries include at least Argentina, Chile, Panama, Canada (Manitoba), Mexico in the Americas; Armenia, Czech Republic, Israel, Malta, Romania, San Marino, Slovakia, and Spain in the European region of ILO; and Iran, Cambodia, China, Mauritius, Seychelles, and Tunisia in Africa and Asia. After researchers have estimated values for each in kind benefit, it is necessary to check that the total for all in kind benefits does not exceed the $30 \%$ allowed.

- Value of an in kind benefit should not exceed amount included in living wage for the item. The reason for this criterion is that it is possible for the value of an in kind benefit based on the above guidelines to exceed the amount included for this item in NFNH costs. If this value were used uncritically, it would mean that the cash living wage (i.e. living wage minus value of in kind benefits) would not be sufficient and this is reflected in expenditure statistics. This situation is most likely to occur when a free in kind benefit is so common in a location that families in that location necessarily do not spend much on this item. Free transport to work is an example of this in locations where most workers commute to work on a company bus or walk. ${ }^{12}$ For example, if a living wage was $\$ 100$ with $\$ 10$ included in living costs for transport and the estimated value of free transport to work of \$20 was used as partial payment of the living wage, the resulting cash living wage of $\$ 80$ would not be sufficient to support a decent living standard, because more would be taken out of the wage for transport than was allotted to transport in the living wage estimate. 


\subsection{Difference between How to Value In Kind Benefits for Discussion with an Industry Value Chain and for Auditing Establishments}

It is necessary to distinguish between the value of in kind benefits provided by typical establishments in an industry used for discussions about an industry value chain and the value of in kind benefits for audits of particular establishments to determine if they pay a living wage. Since each establishment may provide different in kind benefits, this means that each establishment has its own monetary value for in kind benefits. This also means that estimating the value of in kind benefits for an industry is only possible for expositional purposes using typical values for the industry. For example, in an industry where most establishments provide free lunch and free transport but nothing else and these are worth around $20 \%$ of basic pay, the prevailing wage could be said to be 1.2 times basic pay for expositional purposes. This estimate of prevailing wage for the industry could then be compared with the living wage to determine the typical gap between living wage and prevailing wages in the industry. Knowledge of the typical gap in an industry is important for discussions with employers, unions, government, standard setting organizations, and the value chain about wages and the possible need to develop an action plan to increase wages.

When auditing a particular establishment to see whether it pays a living wage, however, it is not appropriate to use the typical value of in kind benefits in an industry. Rather, it is necessary to determine the monetary value of in kind benefits provided by each establishment being audited to determine whether or not it is paying a living wage.

The overall approach used to determine the value of in kind benefits for an industry or an establishment is the same. The only difference is that average values of typical in kind benefits are estimated for an industry whereas values of the in kind benefits actually provided by the establishment are determined for auditing.

\section{PART III. EXAMPLE OF ESTIMATING THE VALUE OF MULTIPLE IN KIND BENEFITS}

A hypothetical example is provided in Table 16.4 to illustrate how in kind benefits should be valued as partial payment of wages for comparison to a living wage. In this example, a range of in kind benefits is provided for illustrative purposes. The cost to the employer and market replacement value are shown for each benefit in Table 16.4 (in a living wage study these values would need to be determined). The base wage plus allowed cash 


\begin{tabular}{|c|c|c|c|c|c|}
\hline 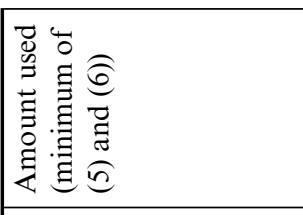 & 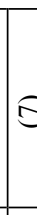 & $\begin{array}{l}\frac{\tilde{D}}{2} \\
\stackrel{\sim}{\infty}\end{array}$ & 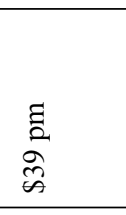 & $\begin{array}{l}\frac{\hbar}{0} \\
\stackrel{0}{\infty} \\
\dot{\infty}\end{array}$ & $\begin{array}{l}\text { I. } \\
0 \\
0 \\
0\end{array}$ \\
\hline 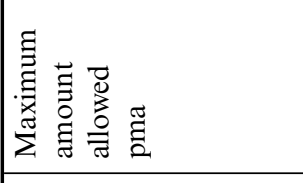 & 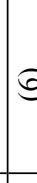 & 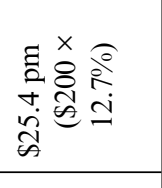 & 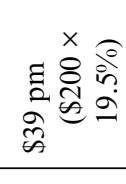 & 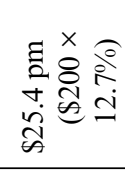 & 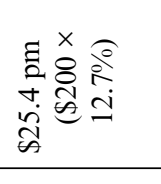 \\
\hline 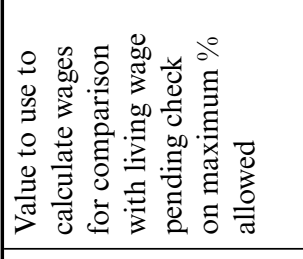 & 5 & 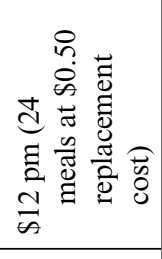 & 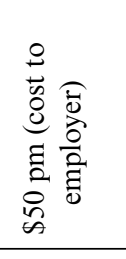 & 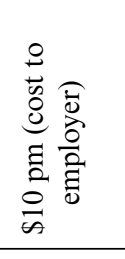 & 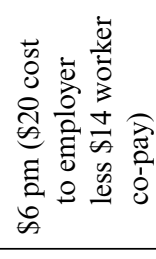 \\
\hline 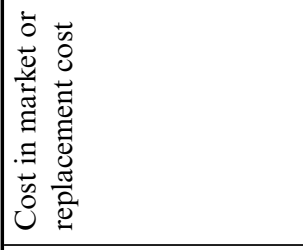 & 9 & 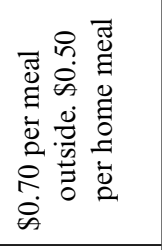 & $\begin{array}{l}\equiv \\
\vdots \\
\vdots \\
\infty \\
\infty\end{array}$ & $\begin{array}{l}\frac{\equiv}{2} \\
\frac{2}{\infty}\end{array}$ & 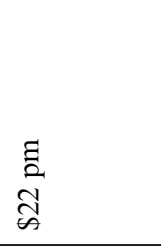 \\
\hline 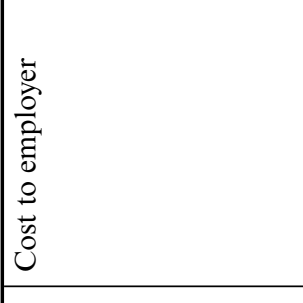 & (3) & 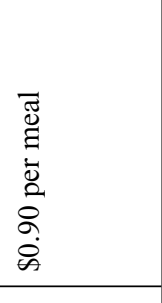 & 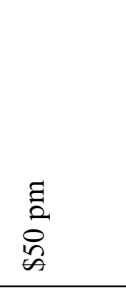 & $\begin{array}{l}\frac{a}{0} \\
\frac{0}{2} \\
\infty\end{array}$ & 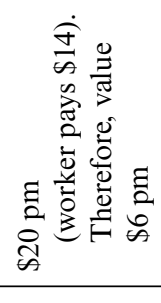 \\
\hline 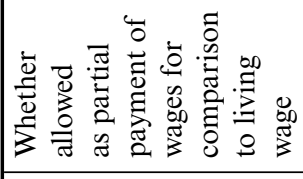 & 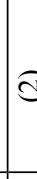 & $\stackrel{0}{\circ}$ & 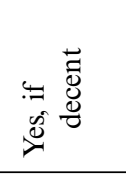 & 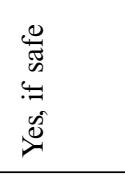 & $\stackrel{\mathscr{D}}{\nu}$ \\
\hline 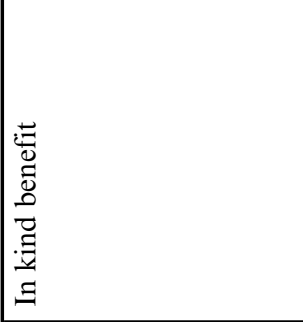 & 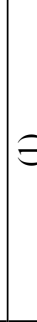 & 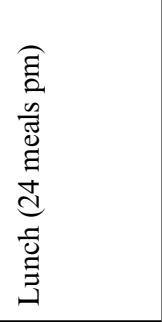 & 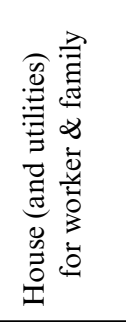 & 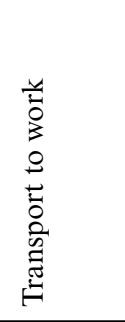 & 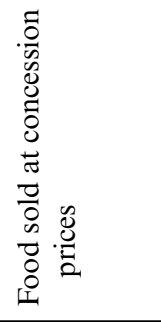 \\
\hline
\end{tabular}




\begin{tabular}{|c|c|c|c|c|c|c|c|c|}
\hline $\begin{array}{l}\tilde{a} \\
\stackrel{1}{\omega}\end{array}$ & 0 & 0 & 0 & $\begin{array}{c}\tilde{\Xi} \\
\tilde{n}\end{array}$ & 0 & 0 & 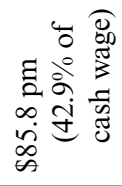 & 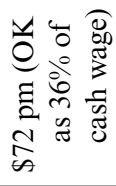 \\
\hline 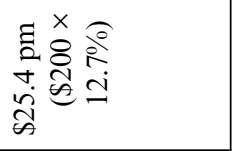 & 0 & 0 & 0 & 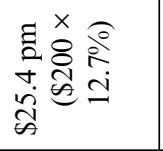 & 0 & 0 & & \\
\hline 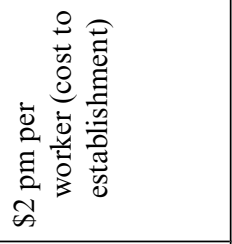 & 0 & 0 & 0 & 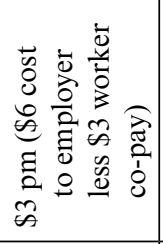 & 0 & 0 & & \\
\hline 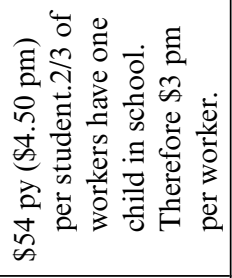 & $\begin{array}{c}\tilde{\Xi} \\
\stackrel{\Xi}{\alpha} \\
\tilde{\infty}\end{array}$ & $\begin{array}{l}\grave{\mathrm{e}} \\
\text { J }\end{array}$ & $\begin{array}{l}\vec{a} \\
n \\
\tilde{n}\end{array}$ & 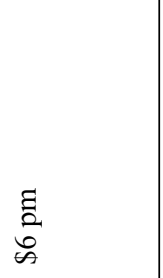 & 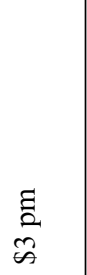 & 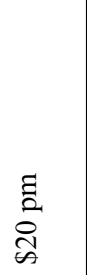 & & \\
\hline 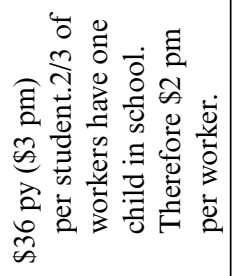 & $\frac{\tilde{L}}{\tilde{\omega}}$ & $\begin{array}{l}\grave{2} \\
i n\end{array}$ & $\begin{array}{l}\overrightarrow{2} \\
\sim \\
\tilde{\omega}\end{array}$ & 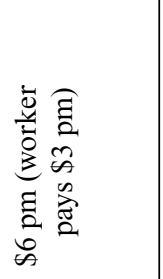 & $\begin{array}{c}\tilde{a} \\
\tilde{n} \\
\tilde{n}\end{array}$ & $\begin{array}{l}\text { हี } \\
\text { مे } \\
\text { ஸे }\end{array}$ & & \\
\hline$\stackrel{0}{\nu}$ & $\stackrel{\circ}{Z}$ & $\stackrel{\circ}{Z}$ & $\stackrel{\circ}{Z}$ & $\stackrel{\infty}{\nu}$ & $\stackrel{\circ}{Z}$ & ż & & \\
\hline 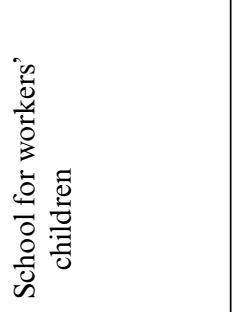 & 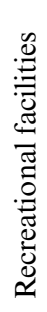 & 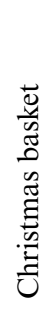 & 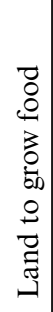 & 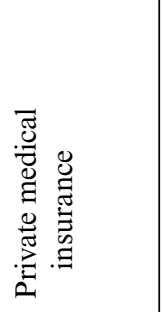 & 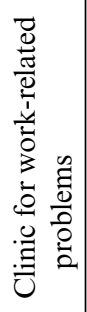 & 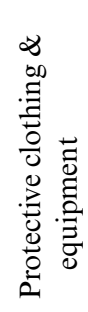 & 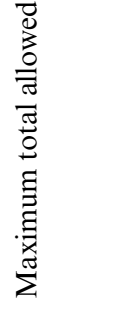 & 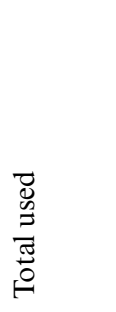 \\
\hline
\end{tabular}


allowances and cash bonuses is assumed to be $\$ 200$ per month in this example.

The first step is to consider whether each in kind benefit should be included in wages for comparison with a living wage. In this example, Christmas basket, land to grow food, clinic for work-related problems, and protective clothing and equipment are excluded and therefore valued at zero (column 5). The cost of protective clothing to the employer is set relatively high in this example to show that even when a work-related benefit such as protective clothing has a high cost and value, it should be excluded because it is not for personal use.

The second step is to estimate the value of each in kind benefit in several ways - its cost to the employer, its market cost, and its replacement cost to the worker. These values are shown in columns 3 and 4. In estimating these values, the following should be kept in mind:

1. All values should be for the same time period. For example, the value of school was converted from annual cost to monthly cost to be consistent with the rest of the table.

2. Worker co-payments should be deducted from values as shown in this example for food sold at concession prices and private medical insurance.

3. For benefits that do not affect all workers, such as school and transport the average value over all workers should be used. Thus the example shows that if school costs the employer $\$ 3$ per student per month, and $2 / 3$ of workers have one child in school, the cost of this benefit to the employer is $\$ 2$ per worker per month.

The lowest of these values for each in kind benefit in columns 3 and 4 should be selected at this point and indicated in column 5 .

The third step is to estimate the maximum value allowed for each in kind benefit and the maximum value allowed for all in kind benefits together based on the rules indicated in Section 16.8 - 15\% of wage for housing, $10 \%$ for each other benefit, and $30 \%$ in total for all in kind benefits (column 6). Estimating maximum value for each in kind benefit is not as simple as it might seem because rules on maximum percentage allowed refer to the total wage received, which includes the value of in kind benefits. For example, if the wage was $\$ 100$ and it consisted of $\$ 70$ cash and $\$ 30$ in kind benefits, in kind benefits would represent 30\% of the total wage and $42.9 \%$ of the cash wage. Most national laws indicate the percentage of a total wage that can be deducted for in kind benefits and so start from total wage and not cash wage, which is where we start. This means that $11.1 \%(1 / .90-1)$ of cash wage is the maximum allowed when there is 
only one in kind benefit and 17.6\% (1/.85-1) is allowed for housing when housing is the only in kind benefit. When there are two or more acceptable in kind benefits, an iterative process is needed where the total value of all in kind benefits is compared to the $42.9 \%(1 / .7-1)$ maximum of cash wages allowed with the lower of these chosen, and then go back and recalculate the maximum of each benefit allowed using this new total wage (cash wage plus new total in kind). Given the difficulty involved in using such an iterative process, we recommend using the following simplified guidelines that approximate the iterative process:

1. Use $11.1 \%(1 / .9-1)$ of cash wages for each allowed in kind benefit besides housing (and 17.6\% for housing) when there is only one acceptable in kind benefit.

2. Use $12.7 \%$ of cash wages for each allowed in kind benefit besides housing when there are two or more acceptable in kind benefits (i.e. average of $11.1 \%$ allowed when one in kind benefit and maximum of $14.3 \%$ allowed when the total value of all in kind benefits equals or exceeds the $30 \%$ of wages limit), and $19.5 \%$ (average of $17.6 \%$ and $21.3 \%$ ) of cash wage for housing.

3. Apply a final check to steps 1 and 2 by adding up the values of all in kind benefits and reduce this total to a maximum of $42.9 \%$ of cash wages when the total exceeds $42.9 \%$ of cash wages.

\section{NOTES}

1. Written authorization is required in California, Maryland, New York and Texas. Connecticut requires employees to agree at time of hiring, and Federal law requires voluntary and uncoerced acceptance of benefits by employees. Federal law (voluntary uncoerced acceptance of benefits by employee required) is weak in practice as 'courts have [generally] held that when an employee accepts a job voluntarily and without coercion, such acceptance automatically includes the in kind benefits the employer may bestow upon the employed' (Luers, 1998, pp. 215-16).

2. Labour Code \$L.96(2)(3); Decree n. 96-178/P-RM, 13 June 1996, on the application of the Labour Code. §D.86-10, D.86-12.

3. South Africa Basic Conditions of Employment Act 1997 as amended 2002 Section 7.

4. New York: New York State Department of Labor, Part 142, Minimum Wage Order for Miscellaneous Industries and Occupations Part 142 of Title 12 of the Official Compilation of Codes, Rules, and Regulations of the State of New York (Part $142-2.20)$.

5. A meal in Chad and Senegal is valued at one hour at the minimum wage. Daily food rations are valued at one hour at minimum wage in Chad and two hours in Senegal. Food rations in Mali are valued at 2.5 hours of minimum wage and accommodation at 0.5 hour of minimum wage.

6. This includes Convention 95 and Recommendation 95 (Protection of Wages, 1949); Convention 99 and Recommendation 89 (Minimum wage fixing machinery (Agriculture), 1951); Convention 110 and Recommendation 110 (Plantations, 1958); 
Recommendation 115 (Workers' Housing, 1961); Convention 117 (Social Policy Basic Aims and Standards, 1962); and Convention 189 and Recommendation 201 (Domestic Workers, 2011). There is also the ILO Tripartite Declaration of Principles Concerning Multinational Enterprises and Social Policy (2006).

7. '1. National laws or regulations, collective agreements or arbitration awards may authorize the partial payment of wages in the form of allowances in kind in [indentation and numbering added for clarity]:

(1) industries or occupations in which payment in the form of such allowances is customary or desirable because of the nature of the industry or occupation concerned;

(2) the payment of wages in the form of liquor of high alcoholic content or of noxious drugs shall not be permitted in any circumstances.

2. In cases in which partial payment of wages in the form of allowances in kind is authorized, appropriate measures shall be taken to ensure that -

(a) such allowances are appropriate for the personal use and benefit of the worker and his family; and

(b) the value attributed to such allowances is fair and reasonable.' (ILO Wages Convention 95)

8. For example, although tea estates in Malawi served lunches that included only beans and rice, we concluded that it would be appropriate to include the value of this lunch as partial payment of a living wage - even though it included only two food groups because Malawi is such a poor country and lunch provided needed calories and proteins.

9. In Malawi, the employers' tea estates organization (TAML) indicated to us that tea estates provided the following list of in kind benefits (with average cost per worker per day in 2013 in kwacha indicated in brackets): meals/drinks (57.5), housing (43.6), water to house (6.5), security for housing compounds (6.2), medical clinic (12.8), school/ crèche (17.2), football team (10.7), funerals for workers who die (20.2), leave grants (18.2), gratuity/severance pay (17.8), and protective clothing (35.4). All together, the value of these in kind benefits summed to $58 \%$ of the basic wage of K560. Many in kind benefits claimed are not considered as partial payment of wages in our methodology. This includes protective clothing (as for work and not for personal use), gratuity (as received when worker leaves employment sometime in future), leave grants (as uncertain and mainly for management), security for housing compounds (as protects tea estate housing assets), and football team (as only for some men).

10. The reason why dormitory accommodation for seasonal workers is not considered to be partial payment of a living wage is because it does not reduce the need for a permanent home for the worker's family.

11. We developed an Excel spreadsheet to calculate the cost of meals prepared at home. See Chapter 3.

12. We have encountered this situation in living wage studies for Mauritius and Sialkot Pakistan. Mauritius labor law requires employers to provide free transport when a worker lives more than 3 kilometers from work (or give cash for public transport). As a result, most workers in Mauritius commute to work in a company bus, and so a considerable portion of transport costs in Mauritius shows up as a business expense and not as a household expenditure in expenditure statistics. Therefore, it is not appropriate to consider free transport to work as partial payment of the living wage in Mauritius because there are relatively few funds for transport included in estimated NFNH costs. 